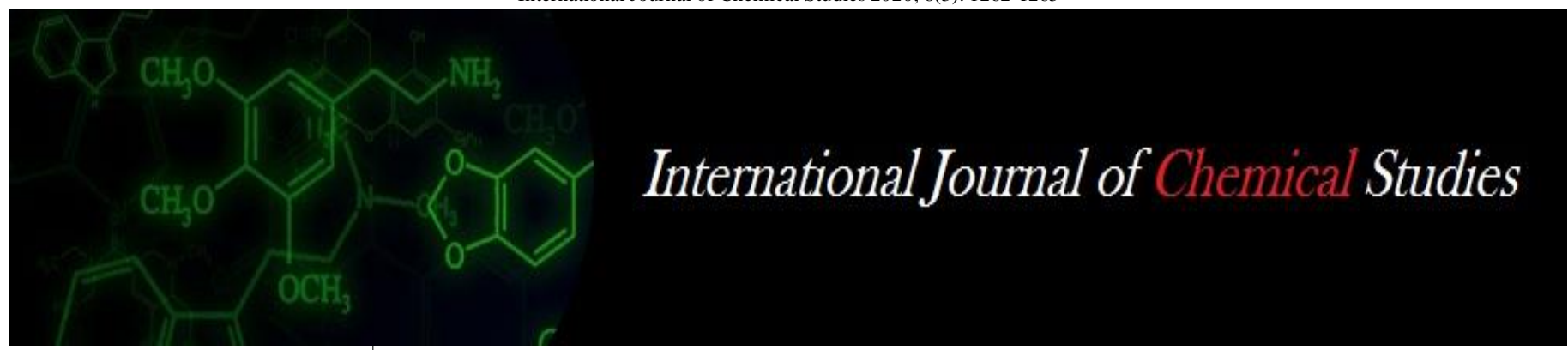

P-ISSN: 2349-8528

E-ISSN: 2321-4902

www.chemijournal.com

IJCS 2020; 8(3): 1262-1265

(C) 2020 IJCS

Received: 18-03-2020

Accepted: 20-04-2020

\section{Preeti Khare}

Department of Agricultural

Extension Indira Gandhi Krishi

Vishwavidyalaya, Raipur,

Chhattisgarh, India

Dr. ML Sharma

Department of Agricultural

Extension Indira Gandhi Krishi

Vishwavidyalaya, Raipur,

Chhattisgarh, India

Uma Rani Singh

Department of Agricultural

Extension Indira Gandhi Krishi

Vishwavidyalaya, Raipur,

Chhattisgarh, India
Corresponding Author:

Preeti Khare

Department of Agricultural

Extension Indira Gandhi Krishi

Vishwavidyalaya, Raipur,

Chhattisgarh, India

\section{Knowledge of rural women in animal husbandry practices}

\section{Preeti Khare, Dr. ML Sharma and Uma Rani Singh}

DOI: https://doi.org/10.22271/chemi.2020.v8.i3q.9374

\begin{abstract}
A survey based study was carried out to ascertain knowledge of rural women in animal husbandry practices in korba district of chhattisgarh, The socio-personal study revealed that majority of the women were middle aged $(69.20 \%)$ in illiterate $(42.50 \%)$, belonged to other backward caste and were engaged in animal husbandry practices. Maximum respondents had nuclear type of family. In the study area, 62.50 per cent respondent landless farmers. majority $(57.50 \%)$ of them had higher level of annual income. 70.00 per cent respondents had medium level of scientific orientation. (67.50\%) had low Cosmopoliteness. majority $(95.00 \%)$ of the respondents used to contact neighbour/friend/relative for information about animal husbandry practices. majority of the respondents $(69.17 \%)$ had medium exposure to overall sources of information. most of the respondents $(44.17 \%)$ had low level of contact with extension personnel. Regarding correlation, out of all selected 10 independent variables, only 5 variables had highly significant correlated with knowledge of women in animal husbandry practices at 0.01 per cent level of significance. Remaining 5 variables did not indicate any significant relationship with knowledge of women in animal husbandry practices. multiple regression analysis was analyzed. The data reveal that out of 10 variables, only 1 variables viz. had highly significant contribution towards knowledge at 0.01 per cent level of significance and 3 variables found positive and significantly contribution towards knowledge of women in animal husbandry practices. remaining 6 variables did not contribute significantly in the knowledge of recommended animal husbandry practices. However, all the selected 10 independent variables in the model shows the 57 per cent contribution in the knowledge of recommended animal husbandry practices.
\end{abstract}

Keywords: Knowledge; rural women; animal husbandry practices

\section{Introduction}

The prosperity and growth of a nation depends on the status and development of its women. women play an important role in animal husbandry activities as manager, decision makers and skilled workers. The Chhattisgarh state is rich in livestock wealth. The total livestock population is over 144.18 lakh. livestock produce about 1120 MT milk production. FYM from dairy animals provides a good source of organic material for improving soil fertility and crop yield. One third of the cattle dung in India is used as fuel in rural areas. women have to be motivated to acquire more scientific knowledge for increasing the livestock production through various extension techniques. knowledge of rural women This effort could be of great utility to the extension managers, policy planners and all those involved in dairy development to devise suitable dairy development activities and also in proper targeting of these activities.

\section{Research methodology}

The present study was carried out during 2012-13 in the Korba district of Chhattisgarh state. This study aims to assess knowledge of rural women in animal husbandry enterprise. this study was conducted in randomly selected 8 villages [aayodhapuri, tulsinagar, Nagoyeekhar, Fertilizer, Kharmora, Gokulnagar, Duggupara and Dahiyanpara] of two purposively selected blocks (Korba and Katghora) located in Korba district. The sample size was comprised of 120 respondents. The data collection was done by the use of interview schedule through personal interview. Data were analyzed with help of suitable statistical methods. 


\section{Results and discussion}

Socio-personal characteristics of the respondents indicated that the majority (69.20\%) belonged to middle age group (31 to 45 years) Bellukar et al. (2003), Rathod et al. (2011), Chand et al. (2011) [3], Hai et al. (2011) [4], and Lad et al. (2012) [9] also noted almost similar findings. Maximum respondents had illiterate Bellukar et al. (2003), Khin (2005) [6], Kavitha and Reddy (2007) [5] also observed similar findings in their study. Majority of the respondents $(42.50 \%)$ belonged other backward caste who were engaged in animal husbandry practices. Maximum respondents had nuclear type of family Savitha (2004) ${ }^{[12]}$, Chand et al. (2011) ${ }^{[3]}$, Lad et al. (2012) ${ }^{[9]}$ and Koundal (2012) ${ }^{[7]}$ also noted almost similar findings.

Table 1: Distribution of the respondents according to their sociopersonal characteristics

$(n=120)$

\begin{tabular}{|c|c|c|}
\hline Characteristics & Frequency & Percentage \\
\hline Age & & \\
\hline Young (up to 30 years) & 21 & 17.50 \\
\hline Middle (31 to 45 years) & 83 & 69.20 \\
\hline Old (above 45 years) & 16 & 13.30 \\
\hline Education & & \\
\hline Illiterate & 51 & 42.50 \\
\hline Only signature & 09 & 07.50 \\
\hline Primary school $\left(1^{\text {st }}\right.$ to $\left.5^{\text {th }}\right)$ & 26 & 21.70 \\
\hline Middle school $\left(6^{\text {th }}\right.$ to $\left.8^{\text {th }}\right)$ & 18 & 15.00 \\
\hline High School $\left(9^{\text {th }}\right.$ to $\left.10^{\text {th }}\right)$ & 09 & 07.50 \\
\hline Higher Secondary School $\left(11^{\text {th }}\right.$ to $\left.12^{\text {th }}\right)$ & 05 & 04.13 \\
\hline Graduate and above & 02 & 01.67 \\
\hline Caste & & \\
\hline Scheduled caste & 00 & 00.00 \\
\hline Scheduled tribes & 00 & 00.00 \\
\hline Other backward class & 82 & 68.30 \\
\hline General & 38 & 31.70 \\
\hline Type of family & & \\
\hline Nuclear & 96 & 80.00 \\
\hline Joint & 24 & 20.00 \\
\hline
\end{tabular}

Table 2: Distribution of the respondents according to their socioeconomic characteristics

$(\mathrm{n}=120)$

\begin{tabular}{|c|c|c|}
\hline Characteristics & Frequency & Percentage \\
\hline \multicolumn{2}{|c|}{ Land holding } \\
\hline Landless farmer & 75 & 62.50 \\
\hline Marginal (up to 1 ha) & 45 & 37.50 \\
\hline Small (1.1 to 2 ha) & 00 & 00.00 \\
\hline Medium (2.01 to 4 ha) & 00 & 00.00 \\
\hline Big (above 4 ha) & 00 & 00.00 \\
\hline \multicolumn{2}{|c|}{ Annual income } \\
\hline Low (up to Rs. 32,500) & 07 & 05.83 \\
\hline Medium (Rs.32,501 to Rs.65,000) & 44 & 36.67 \\
\hline High (above Rs.65,000) & 69 & 57.50 \\
\hline
\end{tabular}

Table 2 Show that Socio-economic characteristics of the respondents indicated that the maximum number of respondents belonged to landless category. Kumari (1999) ${ }^{[8]}$ and Balasubramanian (1995) ${ }^{[1]}$ also observed almost similar findings. majority of the respondents belonged to above Rs.65,000 annual income group. Pushpa (2006) ${ }^{[11]}$ also noted similar findings in her study.

Table 3: Distribution of respondents according to their scientific orientation and Cosmopoliteness

$(\mathrm{n}=120)$

\begin{tabular}{|c|c|c|}
\hline Characteristics & Frequency & Percentage \\
\hline Level of scientific orientation \\
\hline Low (up to 15 score) & 22 & 18.30 \\
\hline Medium (16 to 30 score) & 84 & 70.00 \\
\hline High (above 30 score) & 14 & 11.70 \\
\hline Level of Cosmopoliteness & \\
\hline Nil (Never) & 81 & 67.50 \\
\hline Low (Rarely: 3-4 times in a year) & 28 & 23.30 \\
\hline Medium (Sometimes: 3-4 times in a month) & 11 & 09.20 \\
\hline High (Always: 3-4 times in a week) & 00 & 00.00 \\
\hline
\end{tabular}

Table 3 Show that $(70.00 \%)$ had medium level of scientific orientation. The majority of the respondents $(67.50 \%)$ had nil Cosmopoliteness.

The data presented in Table 4 reveal that amongst the sources of information, majority $(95.00 \%)$ of the respondents used to contact Neighbour/Friend/Relative for information about animal husbandry practices and 91.67 per cent of the respondents contacted with Milk Seller, followed by 88.33 per cent of the respondents contacted with Medicine Shopkeepers and Veterinary Doctors. About 14.17 per cent of the respondents contacted with Progressive Farmers and, 9.17 per cent of the respondents contacted with Rural Agriculture Extension Officer. About 08.33 per cent of the respondents had obtained information from Television, 07.50 per cent from Radio, 09.17 per cent were using Newspaper for seeking information regarding animal husbandry practices and none of them used Veterinary Scientists as their sources of information

Table 4: Distribution of respondents according to their use of sources of information

$(n=120)$

\begin{tabular}{|c|c|c|}
\hline Sources of information & Frequency & Percentage* \\
\hline Neighbour/Friend/Relative & 114 & 95.00 \\
\hline Progressive farmer & 17 & 14.17 \\
\hline Rural Agriculture Extension Officer & 11 & 09.17 \\
\hline Medicine shopkeeper & 106 & 88.33 \\
\hline Veterinary doctor & 106 & 88.33 \\
\hline Veterinary Scientists & 00 & 00.00 \\
\hline Milk seller & 110 & 91.67 \\
\hline Radio & 09 & 07.50 \\
\hline Television & 10 & 08.33 \\
\hline News paper & 06 & 05.00 \\
\hline
\end{tabular}

Data are based on multiple response

Table 5: Distribution of the respondents according to their extent of utilization of sources of information and contact with extension personnel

\begin{tabular}{|c|c|c|}
\hline Characteristics & \multicolumn{2}{c}{ Frequency } \\
\hline \multicolumn{1}{|c|}{ Utilization of information sources } \\
\hline Low utilization (up to 3 sources) & 10 \\
\hline Medium utilization (4 to 6 sources) & 83 & 20 ) \\
\hline High utilization (above 6 sources) & 8.33 \\
\hline Low (up to 5 score) & 69.17 \\
\hline Medium (6-10 score) & 22.50 \\
\hline High (above 10 score) & 53 \\
\hline
\end{tabular}


Table 5 reveals that $(69.17 \%)$ had medium exposure to overall sources of information. Most of the respondents (44.17\%) had low level of contact with extension personnel.

Table 6: Distribution of respondents according to their level of knowledge about selected animal husbandry practices

\begin{tabular}{|c|c|c|c|}
\hline \multicolumn{2}{|c|}{ Level of knowledge } \\
\hline Practices & Nil f/ $(\%)$ & Partial f /(\%) & Full f/ $(\%)$ \\
\hline Knowledge about AI & $59(49.17)$ & $61(50.83)$ & $00(00.00)$ \\
\hline Knowledge about animal breed & $85(70.83)$ & $35(29.17)$ & $00(00.00)$ \\
\hline Knowledge about nutrient of animal & $41(34.17)$ & $74(61.66)$ & $05(04.17)$ \\
\hline Knowledge about how much nutrient to be given to pregnant and milch animals & $00(00.00)$ & $119(99.17)$ & $01(00.83)$ \\
\hline Knowledge about how much nutrient to be given to new born calf & $00(00.00)$ & $116(96.67)$ & $04(03.33)$ \\
\hline Knowledge about suitable management for animal & $11(09.17)$ & $104(86.66)$ & $05(04.17)$ \\
\hline Knowledge about animal diseases & $69(57.50)$ & $51(42.50)$ & $00(00.00)$ \\
\hline Knowledge about different medicines for animal's treatment & $117(97.50)$ & $03(02.50)$ & $00(00.00)$ \\
\hline Knowledge about animal vaccines & $120(100)$ & $00(00.00)$ & $00(00.00)$ \\
\hline Knowledge about insurance related to animal & $120(100)$ & $00(00.00)$ & $00(00.00)$ \\
\hline
\end{tabular}

f- Frequency; (\%) - Per cent

Table 7: Distribution of respondents according to their overall level of knowledge regarding animal husbandry practices

$(n=120)$

\begin{tabular}{|c|c|c|}
\hline Level of knowledge & Frequency & Percentage \\
\hline Low (Up to $33.33 \%$ ) & 24 & 20.00 \\
\hline Medium (33.34 to 66.66\%) & 70 & 58.33 \\
\hline High (above $66.66 \%$ ) & 26 & 21.67 \\
\hline
\end{tabular}

Table $6 \& 7$ reveals that 58.33per cent of the respondents had medium level of overall knowledge regarding animal husbandry practices. In case of practice wise level of knowledge of respondents it was found that 50.83 per cent of the respondents had partial level of knowledge about artificial insemination, 70.83 per cent of the respondents had no knowledge about animal breed, 61.66 per cent of the respondents had partial level of knowledge about nutrition of animal, 99.17 per cent of the respondents had partial level of knowledge about nutrition to be given to pregnant and milch animals, 96.67 per cent of the respondents had partial level of knowledge about nutrition to be given to new born calf, 86.66 per cent of the respondents had partial level of knowledge about suitable management for animal, 57.50 per cent of the respondents had no knowledge about animal diseases, 97.50 per cent of the respondents had no knowledge about different medicines for animal treatment and cent per cent of the respondents had no knowledge about animal vaccines and insurance related to animal.

Table 8: Correlation and multiple regression analysis of independent variables with the knowledge of recommended animal husbandry practices followed by rural women

\begin{tabular}{|c|c|c|c|}
\hline \multirow{2}{*}{ Independent variables } & Correlation coefficient & \multicolumn{2}{|c|}{ Partial regression coefficient } \\
\cline { 2 - 4 } & $\mathbf{\text { 'r' value }}$ & 'b' value & 't' value \\
\hline $\mathrm{X}_{1}$ Age & 0.127555 & $0.020791^{*}$ & 2.347882 \\
\hline $\mathrm{X}_{2}$ Education & 0.170166 & 0.065912 & 1.858791 \\
\hline $\mathrm{X}_{3}$ Caste & 0.10297 & 0.820813 & 0.227078 \\
\hline $\mathrm{X}_{4}$ Type of family & 0.015744 & 0.80893 & 0.242429 \\
\hline $\mathrm{X}_{5}$ Land holding & 0.070309 & 0.094759 & 1.686329 \\
\hline $\mathrm{X}_{6}$ Annual income & $0.363183^{* *}$ & $0.001804^{*} *$ & 3.204102 \\
\hline $\mathrm{X}_{7}$ Scientific orientation & $0.499666^{* *}$ & $0.024378^{*}$ & 2.284746 \\
\hline $\mathrm{X}_{8}$ Cosmopoliteness & $0.23866^{* *}$ & $0.022114^{*}$ & -2.32355 \\
\hline $\mathrm{X}_{9}$ Source of information & $0.331283^{* *}$ & 0.25377 & 1.147655 \\
\hline $\mathrm{X}_{10}$ Contact with extension personnel & $0.375036^{* *}$ & 0.172216 & 1.374673 \\
\hline ** Significant at 0.01 level of probability & \multicolumn{3}{|c|}{ Multiple $\mathrm{R} 2=0.571694$} \\
\hline * Significant at 0.05 level of probability & $\mathrm{F}$ value $=9.24$ \\
\hline
\end{tabular}

Table 8 reveals that out of all selected 10 independent variables, only 5 variables i.e. annual income, Scientific orientation, Cosmopoliteness, Source of information, contact with extension personnel had highly significant correlated with knowledge of women in animal husbandry practices at 0.01 per cent level of significance correlated with knowledge of women in animal husbandry practices. Remaining 5 variables did not indicate any significant relationship with knowledge of women in animal husbandry practices. To determine the predicting ability of various independents variables, multiple regression analysis was analyzed. The data reveal that out of 10 variables, only 1 variables viz. Annual income highly significant contribution towards knowledge at 0.01 per cent level of significance and 3variables age, Scientific orientation, Cosmopoliteness, found positive and significantly contribution towards knowledge of women in animal husbandry practices remaining 6 variables did not contribute significantly in the knowledge of recommended animal husbandry practices. majority $(95.00 \%)$ of the respondents used to contact Neighbour/Friend/Relative for information about animal husbandry practices However, all the selected 10 independent variables in the model shows the 57 per cent contribution in the knowledge of recommended animal husbandry practices.

\section{Conclusions}

It was concluded that majority of the women were middle aged $(69.20 \%)$ in illiterate $(42.50 \%)$, belonged to other backward caste and were engaged in animal husbandry practices. Maximum respondents had nuclear type of family. 
In the study area, 62.50 per cent respondent landless farmers. majority $(57.50 \%)$ of them had higher level of annual income. 70.00 per cent respondents had medium level of scientific orientation. (67.50\%) had low Cosmopoliteness. majority $(95.00 \%)$ of the respondents used to contact neighbour/friend/relative for information about animal husbandry practices. majority of the respondents $(69.17 \%)$ had medium exposure to overall sources of information. most of the respondents $(44.17 \%)$ had low level of contact with extension personnel. had medium level of overall knowledge regarding in animal husbandry practices. However, all the selected 10 independent variables in the model shows the 57 per cent contribution in the knowledge of recommended animal husbandry practices.

\section{References}

1. Balasubramanian M. A Study on the Constraints of Buffalo Farming in Chengalpattu-MGR district. M.V.Sc. Thesis, TANUVAS Chennai, 1995.

2. Bellurkar CM, Wakle PK, Gholve MA. xA Study on Decision Making Pattern and Participation of Rural Women in Animal Husbandry and Dairying Enterprise. Maharashtra Journal of Extension Education. 1995; 22(3):81-85.

3. Chand P, Smita S, Rathi D. Assessment of Women Empowerment in Dairying: A Study of Semi-arid Rajasthan. Indian J. Dryland Agric. Res. And Dev. 2011; 26(2):28-32.

4. Hai A, Akand AH, Shanaz S, Bulbul KH. Contribution of farm Women Towards Dairy Enterprise in Ganderbal District of Kashmir Valley. J. Dairying, Foods \& H.S. 2011; 30(2):140-146.

5. Kavitha L, Reddy MS. Personal and Socio-Economic Characteristics of farm Women. J. Res. ANGRAU. 2007; 35(1):79-83.

6. Khin MO. Knowledge and Adoption of Improved Dairy Management Practices by Women Dairy Farmers in Dharwad District. M.Sc (Ag.) Thesis, University of Agricultural Sciences, Dharwad, 2005.

7. Koundal V. Gender Participation and Role of Nomadic Gujjar Women in Animal Husbandry Activity in Jammu and Kashmir. International Journal of Social Science Tomorrow. 2012; 1(2):1-5.

8. Kumari P. Adoption of Improved Household and Agricultural Technologies by Rural Women. Journal Extention Edn. 1999; 10(1):2313-2317.

9. Lad AS, Wattamwar VT, Bothikar GR. Correlates of Participation of Farm Women in Decision Making. Agri. Sci. Digest. 2012; 32(1):52-54.

10. Mundhwa AB, Padheria MN. A study on Profile of Dairy Entrepreneur Women and their Problems and Suggestions Regarding Dairy Farming. Gujarat Agric. Univ. Res. J. 1998; 24(1):52-57.

11. Pushpa P. A study on Livestock Production Systems of Rural and Peri-urban Livestock Owners. M.Sc. (Ag.) Thesis, University of Agricultural Sciences, Dharwad, 2006.

12. Savitha SS. Role of Rural Women in Animal Husbandry. M.Sc. (Ag.) Thesis, University of Agricultural Sciences, Dharwad, 2004.

13. Singh D, Sangwan SP. Knowledge Level of Rural Women about Improved Breeding and Reproductive Practices of Buffalo in Haryana. Indian Journal of Dairy Science. 2006; 59(5):317-321. 